\title{
Fenugreek (Trigonella foenum-graceum) increases postmenopausal fibroblast-associated COL1A1 and COL3A1 production dominantly through its binding to estrogen receptor beta
}

\author{
Shannaz Nadia Yusharyahya ${ }^{1 *}$, Kusmarinah Bramono ${ }^{1}$, Andon Hestiantoro ${ }^{2}$, Sarah Qanita Edwar ${ }^{1}$, Indra Kusuma ${ }^{3}$ \\ ${ }^{1}$ Department of Dermatoveneorology, Faculty of Medicine, Universitas Indonesia, Jakarta, Indonesia. \\ ${ }^{2}$ Department of Obstetric and Gynecology, Faculty of Medicine, Universitas Indonesia, Jakarta, Indonesia. \\ ${ }^{3}$ Physiology Department, Faculty of Medicine, Universitas YARSI, Jakarta, Indonesia.
}

\begin{tabular}{l}
\hline ARTICLE INFO \\
\hline Received on: $28 / 10 / 2019$ \\
Accepted on: $21 / 02 / 2020$ \\
Available online: $04 / 04 / 2020$
\end{tabular}

Key words:

COL1A1, COL3A1, estrogen receptors, fenugreek, human dermal fibroblasts.

\begin{abstract}
In postmenopausal women, oral or topical administration of estradiol increases skin thickness and collagen synthesis, such as collagen type 1 alpha 1 (COL1A1) and collagen type 3 alpha 1 (COL3A1). Due to undesirable side effects of estradiol, such as risks of breast and endometrium pathology, topical phytoestrogens are alternative treatments for aging-related skin changes. Phytoestrogen is a nonsteroidal substance derived from plants, like fenugreek (Trigonella foenum-graceum L.), which has an estrogen like composition that appears to mimic estradiol. The mechanism of action remains unknown, especially in fibroblast-associated COL1A1 and COL3A1 production. In vitro experiments were conducted using postmenopausal women's fibroblasts with estrogen receptor (ER) antagonists. Cell isolation used explant and enzymatic techniques with ELISA kit (MyBioSource, California) for COL1A1 and COL3A1. Paired student $t$-tests compared results between control (no treatment), fenugreek extract $2 \mu \mathrm{g} / \mathrm{ml}$ alone, fenugreek extract 2 $\mu \mathrm{g} / \mathrm{ml}$ with receptor antagonists for $\mathrm{ER} \alpha, \mathrm{ER} \beta$, and both receptors. Greater suppresion of COL1A1 and COL3A1 were shown by both antagonists ER $\alpha$ / ER $\beta$ group and antagonist ER $\beta$ group compared to antagonist ER $\alpha$ group. These results indicate that the fenugreek increases secretion of COL1A1 and COL3A1 through ER $\alpha$, ER $\beta$, and is mainly mediated by ER $\beta$ in post menopausal women's fibroblasts.
\end{abstract}

\section{INTRODUCTION}

The skin undergoes anatomical and physiological changes due to a complex and multifactorial aging process (Strnadova et al., 2019). Aged skin is characterized by wrinkles, reduced skin elasticity, impaired wound healing function, age spots, thinner and drier skin (Parrado et al., 2019). The skin aging process is caused by intrinsic factors (chronological aging) and extrinsic factors (photoaging) which work synergistically (Borg et al., 2013; Kammeyer and Luiten, 2015).

Menopause is the permanent cessation of the menstrual cycle (amenorrhea) due to low estrogen production caused by the

\section{"Corresponding Author}

Shannaz Nadia Yusharyahya, Department of Dermatoveneorology, Faculty of Medicine, Universitas Indonesia, Jakarta, Indonesia.

E-mail:nadiayusharyahya@yahoo.com decline of ovarian function (Calleja-Agius et al., 2013; Santoro and Johnson, 2019). Low serum estrogen in postmenopausal women can accelerate the process of skin aging, such as decreased production of type 1 alpha 1 collagen (COL1A1) and collagen type 3 alpha 1 (COL3A1) to only 30\% (Thornton, 2013; Wilkinson and Hardman, 2017). The process of skin aging, including decreased skin collagen production due to menopausal conditions, can be prevented and treated with hormone therapy (Jia et al., 2015).

Estrogen regulates various physiological functions: cell growth, reproduction, cell differentiation, and development. The primary source of estrogen synthesis is originated from the ovaries, especially $17 \beta$-estradiol (E2) in premenopausal women. Whereas in postmenopausal women, the production of E2 results from testosterone and androstenedione conversion by the action of the enzyme, aromatase in certain cells, which occurs in the breast, brain, and fatty tissue as paracrine or intracrine factors (Jia et al., 2015). 
The cellular function of estrogen is mediated by estrogen receptor alpha $(\mathrm{ER} \alpha)$ and estrogen receptor beta $(\mathrm{ER} \beta)$. $\mathrm{ER} \alpha$ is found in the reproductive tissue, i.e., ovaries and uterus, the breasts, kidney, white fatty tissue, and liver, while ER $\beta$ is found in the ovaries, central nervous system, cardiovascular system, the lungs, colon, kidney, and immune system (Jia et al., 2015). Both estrogen receptors are nuclear hormone receptors sharing an identity similar to amino acids, especially in high DNA-binding domains, which is $97 \%$ and ligand-binding domain of $54 \%$. However, it has very few similarities in other domains. E2 has a potent effect as a steroid sex hormone compared to other estrogen hormones, i.e., estrone and estriol (Lephart, 2018).

The research by Lephart (2018) revealed that ER $\beta$ selective agonist administration provided a protective effect on breast and prostate cancer, thus it might be extrapolated that this treatment modality may have a similar effect on the skin. Immunohistochemistry examination showed that both receptors were found in the skin, and ER $\beta$ in the epidermis significantly decreased after the age of 50 years (Lephart, 2018). In postmenopausal women, estrogen supplementation will give signals toward both receptors, especially $\operatorname{ER} \beta$, to delay the skin aging process (Wilkinson and Hardman, 2017).

The structure and function of the skin are affected by its components, especially dermal fibroblasts. In cell culture, the fibroblasts are identified according to their shape, i.e., spindleshaped and loose growth pattern.

Estrogen performed high protective functions in the aging process. However, there are several controversies regarding the risk of hormone therapy (HT) if used for a prolonged period, especially as a treatment for skin aging alone. Several epidemiological studies reported a correlation between HT and reproductive organ cancer. Therefore, studies were conducted with other substances that mimic estrogen but without side effects or lighter side effects (Lephart, 2018).

Phytoestrogen is a nonsteroidal substance derived from plants with estrogen-like composition (Chen et al., 2015). Phytoestrogen as selective estrogen receptor modulator has a structure that produces estrogenic and antiestrogenic effects based on the level of estrogen hormone in the blood circulation. Phytoestrogen is a nonsteroidal substance with similarity to the $17 \beta$-estradiol structure which can bind the estrogen receptor, i.e., ER $\alpha$ and ER $\beta$ (Pilsakova et al., 2010). Currently, there have been many studies emerging about the benefits of using phytoestrogens as an alternative to hormone therapy to improve or reduce the negative impact of the skin aging process due to menopausal conditions in women (Chen et al., 2015).

Phytoestrogens are comprised more than 100 substances grouped based on their chemical structure. They are divided into two large groups, which are flavonoids and non-flavonoids. The former comprised isoflavones (genistein, daidzein, bochanin A, and formononetin), flavones (luteolin, apigenin, and tageretin), and coumestans (coumestrol and 4-metroxycoumestrol) which are often found in soybean (Kapuscinska and Nowak, 2015; Pilsakova et al., 2010). Non-flavonoid group, i.e., lignan (matairesinol and secoiso-lacriresinol-diglucoside) and resorcinol derivates (resveratrol) are often found in flaxseed, seeds, fruits, and vegetables (Kapuscinska and Nowak, 2015; Nikolić et al., 2017). The highest phytoestrogen can be found in soybean and other sources, such as fenugreek, wheat, blackcurrant, sesame seeds, ginseng, and berries (Panche et al., 2016).

Fenugreek (Trigonella foenum-graceum L.) is one of the plants often used as a food ingredient or herbal medicine. The most processed part is its seed. In culinary arts, fenugreek seed is used with curry seasonings in Indonesia and India. In China, fenugreek is used as the traditional medicine for lower limb edema, as well as lactation stimulant in India (Wani and Kumar, 2018). Fenugreek is a plant that contains various substances, i.e., yamogenin, gitogenin, tigogenin, and trigoneoside. Besides that, fenugreek contains fatty acids, alkaloids (trigonelline and gentianin), flavonoids (vitexin, isovitexin, orientin, vicenin, quercetin, and luteolin), saponin, nicotinamide, and choline (Agustini et al., 2015).

Based on the previous study on the comparison of Collagen Type 1 Alpha 1 (COL1A1) and Collagen Type 3 Alpha 1 (COL3A1) secretion on postmenopausal women's fibroblasts (Human Dermal Fibroblast/HDF), the administration of $2 \mu \mathrm{g} / \mathrm{ml}$ of fenugreek extract significantly increased collagen secretion compared to control (no-treatment) and $5 \mathrm{nM}$ estradiol (Yusharyahya et al., 2019). This study aimed to identify the mechanism of action, especially in fibroblast-associated COL1A1 and COL3A1 production.

\section{MATERIALS AND METHODS}

\section{Experimental}

This research was an in vitro experimental study on fibroblasts in residual tissue from blepharoplasty procedures. The inclusion criteria in this study were: women who had menopause for 2-5 years, estradiol level of $<30 \mathrm{pg} / \mathrm{ml}$, facial wrinkles, and consent to donate their tissue for this study. The exclusion criteria were: facial dermatitis, history of supplement, or hormonal medicine intake within the last 12 months, history of applying products that contain retinoic acid/hydroquinone or their derivates on the face, history of facial radiation/facelift/implant therapy within the last 5 years, and history of ovariectomy procedure.

The donated fibroblasts are referred to as HDF which were isolated, cultured, and stored in the Biorepository Department of YARSI University Integrated Research Laboratory, Jakarta. The cell isolation technique performed in this study was explant and enzymatic according to the procedures described by Hadi et al. (2014) and Kusuma and Hadi ( 2013).

Fenugreek seeds were obtained from Badan Penelitian Tanaman Obat, Tawangmangu, Solo, Indonesia through methanol extraction process by the Agency for the Assessment and Application of Technology (Badan Pengkajian dan Penerapan Teknologi). The dose of fenugreek extract referred to the previous study, i.e., the optimal dose of $2 \mu \mathrm{g} / \mathrm{ml}$ with completed media solvent (Yusharyahya et al., 2019).

\section{Culture of HDF}

HDF culture was conducted in the YARSI Laboratory in 2-3 passages using 24-well culture plate with Dulbecco's Modified Eagle Medium DMEM (Gibco ${ }^{\mathrm{TM}}$, New York), 10\% FBS supplementation (Gibco ${ }^{\mathrm{TM}}$, New York), $1 \%$ antibiotic-antimycotic (Gibco ${ }^{\mathrm{TM}}$, New York) at $37^{\circ} \mathrm{C}$ and $5 \% \mathrm{CO}_{2}$. Three repetitions of 2 $\times 10^{4}$ cells were planted with each estrogen receptor antagonist, i.e., MPP dihydrochloride (Santa Cruz Biotechnology, TX) as 
ER $\alpha$ antagonist, ICI 182, 780 (Santa Cruz Biotechnology, TX) as ER $\alpha$ and ER $\beta$ antagonist, and PHTPP (Santa Cruz Biotechnology, TX) as ER $\beta$ antagonist. The concentration on these antagonists refers to the $\mathrm{Ki}$ value (half-maximum inhibition). The cells were cultured until $80 \%$ confluent, collected and counted using trypan blue exclusion method on TC20 automated cell counter (Bio$\left.\operatorname{Rad}^{\mathrm{TM}}, \mathrm{CA}\right)$.

\section{ELISA test on COL1A1 and COL3A1}

There were five groups: control group with no treatment (K) and fenugreek treatment group with $2 \mu \mathrm{g} / \mathrm{ml}$ concentration (KL2), fenugreek and ER $\alpha$ antagonist (MPP dihydrochloride), ER $\beta$ antagonist (PHTPP), ER $\alpha$ and ER $\beta$ antagonist (ICI 182, 780).

The samples from all of the groups were derived from HDF cells cultured in 24 well plates until the fibroblasts reached $80 \%$ confluence. The obtained HDF cells with condition medium were centrifuged according to the ELISA protocol and stored at $80^{\circ} \mathrm{C}$. After exposure to treatment for 24 hours, the cells were harvested and calculated using trypan blue exclusion method in TC20 automated cell counter (Bio-Rad $\left.{ }^{\mathrm{TM}}, \mathrm{CA}\right)$. ELISA duplication was done using ELISA collagen kit, i.e., COL1A1 and COL3A1 (MyBioSource, CA) with 1:2 and 1:20 dilution for COL1A1 and COL3A1, respectively.

The absorbency rate was measured according to the guidance listed in the multiplate reader protocol (TECAN). The result was subtracted from the blank absorbency rate. The result was then converted into collagen concentration using the standard curve and adjusted to the previously counted living cells. Obtained data were presented in collagen concentration $(\mathrm{ng} / \mathrm{ml})$ of $10^{5}$ living cells.

\section{Statistical analysis}

Statistical analysis was processed by paired $t$-test with an alpha value of 0.05 through Microsoft Excel 2016. This study received ethical clearance from the Health Ethics Committee of the Faculty of Medicine-RSCM (Health Research Ethics Committee, Faculty of Medicine, Universitas Indonesia / Dr. Cipto Mangunkusumo General Hospital, Jakarta, Indonesia).

\section{RESULTS}

\section{Culture of HDF}

This study successfully isolated post-blepharoplasty HDF from postmenopausal women using explant technique. There are two different types of cells, such as spindle-shaped fibroblasts with keratinocytes that resemble cobblestones (Fig. 1) and spindleshaped fibroblasts predominantly without keratinocytes (Fig. 2).

\section{Fenugreek as a ligand to $\mathrm{ER} \alpha$ and $\mathrm{ER} \beta$}

In this study, the administration of $2 \mu \mathrm{g} / \mathrm{ml}$ fenugreek extract increased the secretions of COL1A1 (Fig. 3) and COL3A1 (Fig. 4) from HDF culture. The secretion of COL1A1 from HDF was higher than the secreted protein in the control group, ER $\alpha$ antagonist group, ER $\alpha$ / ER $\beta$ antagonist group, and ER $\beta$ antagonist group (Fig. 3). The exposure of ER $\alpha$ to their antagonist (MPP) appeared to partially inhibit the secretion of COL1A1 $(5.49 \mathrm{ng} / \mathrm{ml})$ from HDF cultures added with $2 \mu \mathrm{g} / \mathrm{ml}$ fenugreek extract (MPP/ Fig. 3). Meanwhile, the administration of ER $\alpha$ / ER $\beta$ antagonist

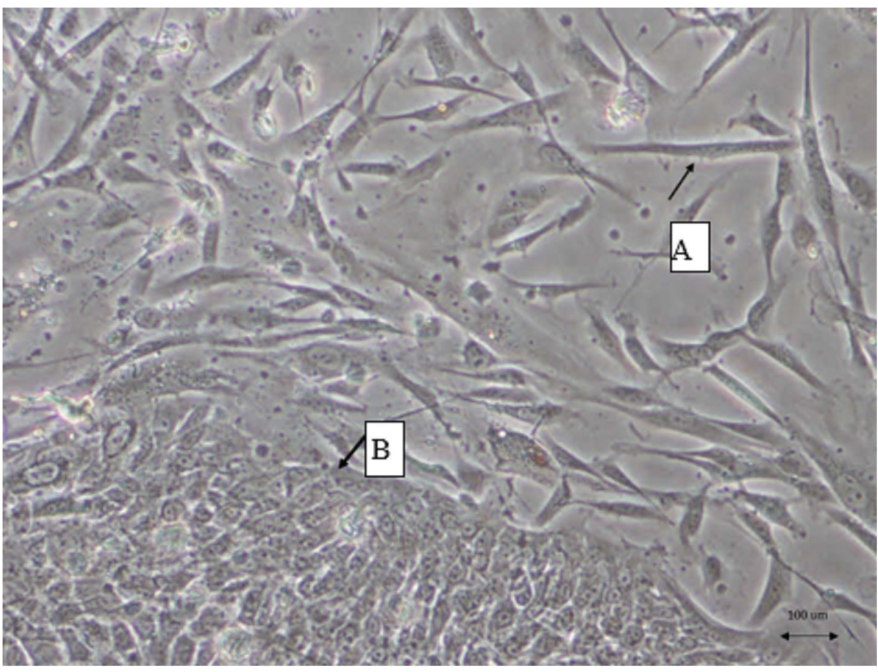

Figure 1. The culture cells of postmenopausal skin after blepharoplasty, depicting fibroblast cells (A) and keratinocytes (B).

(ICI) and ER $\beta$ antagonist (PHTPP) could suppress the greater secretion of COL1A1 (2.63 and $2.71 \mathrm{ng} / \mathrm{ml})$ from HDF cultures stimulated by $2 \mu \mathrm{g} / \mathrm{ml}$ fenugreek extract (ICI and PHTPP/Figure 3 ). We did not observe any statistically significant differences in Col1A1 secretion between the ER $\alpha$ / ER $\beta$ antagonists (ICI) and $\mathrm{ER} \beta$ antagonist (PHTPP) groups.

Moreover, although there was a large suppression of COL1A1 secretion, the addition of antagonist to either ER $\alpha$ / ER $\beta$ or ER $\beta$ did not appear to be able to suppress COL1A1 secretion until it was completely depleted (see Fig. 3).

The secretion of COL3A1 from HDF was also found to be greater $(13.25 \mathrm{ng} / \mathrm{ml})$ than that secreted by the control group, the ER $\alpha$ antagonist group, the ER $\alpha$ / ER $\beta$ antagonist group, and the ER $\beta$ antagonist group (Fig. 4.). Moreover, administration of ER $\alpha$ antagonists (MPP) to HDF culture added with $2 \mu \mathrm{g} /$ $\mathrm{ml}$ fenugreek, resulting in only partial inhibition of COL3A1 secretion $(5.76 \mathrm{ng} / \mathrm{ml})$ (MPP/Fig. 4), whereas the addition of either ER $\alpha$ / ER $\beta$ antagonist (ICI) or ER $\beta$ antagonist (PTPP) to HDF cells culture stimulated by fenugreek extract $2 \mu \mathrm{g} / \mathrm{ml}$ showed a greater inhibition of COL3A1 production (3.34 and 3.82 $\mathrm{ng} / \mathrm{ml})$, compared to the protein secretions after being inhibited with ER $\alpha$ antagonist $(5.76 \mathrm{ng} / \mathrm{ml}$ ) (ICI and PHTPP/Fig. 4). We did not observe any statistically significant differences in Col3A1 secretion between ER $\alpha$ / ER $\beta$ antagonist (ICI) and ER $\beta$ antagonist (PTPP) groups.

The findings were similar even though there was a large suppression of COL3A1 secretion, but the addition of antagonist of either $E R \alpha / E R \beta$ or $E R \beta$ did not seem to be able to suppress COL3A1 secretion until it was completely exhausted (see Fig. 4).

This study used paired Student $t$-tests between control and treatment group $(p<0.05)$. The antagonists used were MPP dihydrochloride (ER $\alpha$ antagonist), ICI 182, 780 (ER $\alpha$ and ER $\beta$ antagonist), and PHTPP (ER $\beta$ antagonist) to determine the collagen secretion inhibitory function of COL1A1 and COL3A1. We found that ER $\alpha$ and ER $\beta$ antagonists (ICI 182, 780) played a role as the most potent inhibitory power, followed by ER $\beta$ antagonist (PHTPP), then ER $\alpha$ antagonist (MPP dihydrochloride). 

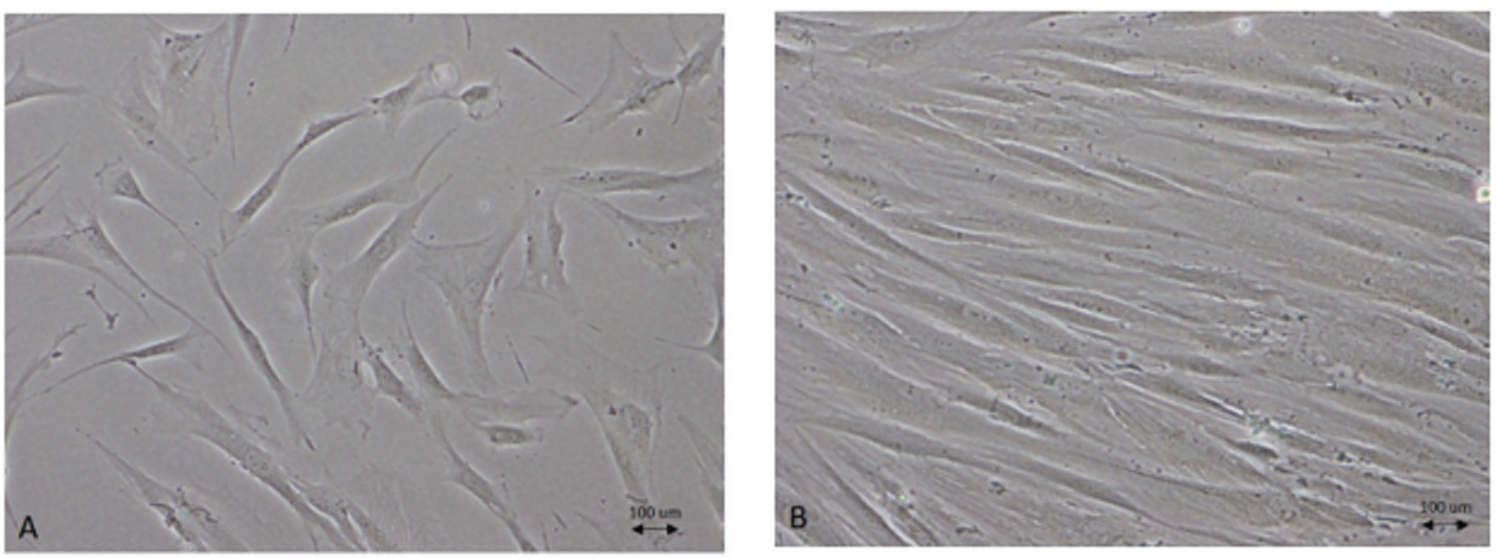

Figure 2. The culture cells of postmenopausal skin after blepharoplasty depicting fibroblast cells without keratinocytes (A and B). The growth of trophoblastic cells could be observed since the first day of culture (A), and showed more growth in the second day of culture (first passage) (B). (P0: Primary isolate originating from the explant P1: First Passage Culture).

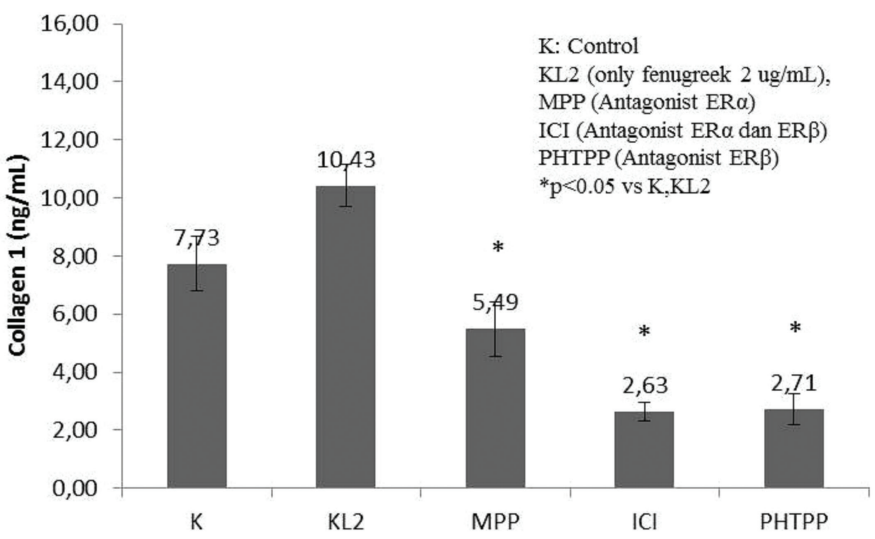

Figure 3. Increased secretion of COL1A1 from HDF cells culture after exposure to $2 \mu \mathrm{g} / \mathrm{ml}$ of fenugreek. The secretion were suppressed on exposure to both ER $\alpha / E R \beta$ antagonist or ER $\beta$ antagonist, greater than on exposure to ER $\alpha$ antagonist.

\section{DISCUSSION}

\section{Fibroblast cell culture from skin tissue of postmenopausal} women

We succeeded in culturing HDF cells and growing them on culture media. This HDF cell culture was challenging, considering the skin tissue obtained after blepharoplasty was only very limited and small. As a consequence, some modifications to the isolation technique needed to be done, such as reducing the frequency and duration of decontamination of the sample to only one minute, whereas for larger skin samples such as the prepuce, we tried longer duration of decontamination successfully (Kusuma and Hadi, 2013). This small size of skin tissue also complicates enzymatic isolation to separate dermal and epidermal layers.

The culture medium used for HDF was DMEM with FBS supplementation, thus HDF selection is expected. In our HDF cell culture, we found a group that only showed the dominance of spindle-shaped cells without the growth of keratinocyte cells (Fig. 2). This raises some questions, considering keratinocyte cells that produce keratin proteins are important cells in the epidermal layer. It is known that keratinocyte cells need an environment with

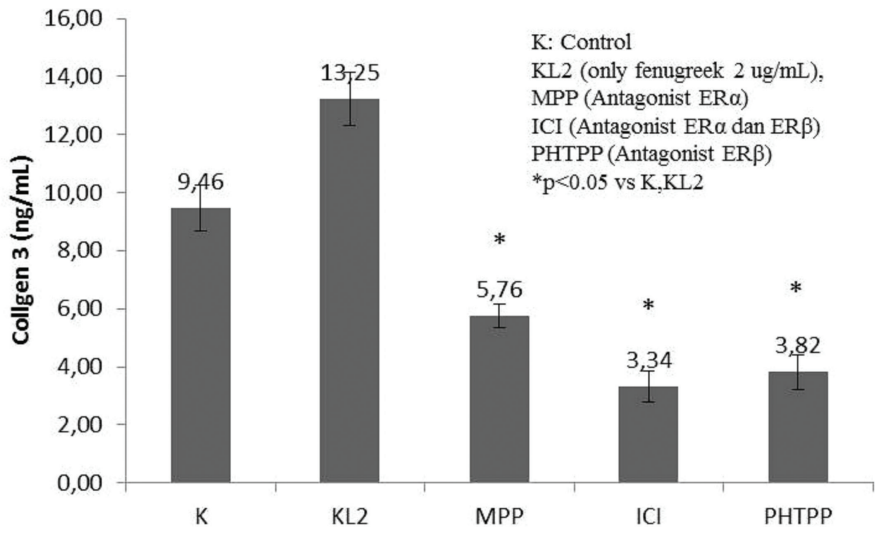

Figure 4. Increased secretion of COL3A1 from HDF cells culture after exposure to $2 \mu \mathrm{g} / \mathrm{ml}$ of fenugreek. The secretion were suppressed on exposure to both $E R \alpha / E R \beta$ antagonist or ER $\beta$ antagonist, greater than on exposure to ER $\alpha$ antagonist.

low calcium levels in order to develop properly (Aasen et al., 2008). Therefore, we speculate that culture media which has high calcium levels would inhibit the growth of keratinocyte cells.

\section{Fenugreek as a ligand to $\operatorname{ER} \alpha$ and $\operatorname{ER} \beta$}

To determine which estrogen receptor mediates the mechanism of fenugreek related to collagen formation from HDF, we performed inhibitory tests using several receptor antagonists, namely, ER $\alpha$ / ER $\beta, E R \alpha$, and ER $\beta$ antagonists. The results showed that $\mathrm{ER} \alpha$ and $\mathrm{ER} \beta$ antagonists (ICI 182, 780) maintained the strongest inhibition, followed by ER $\beta$ antagonists (PHTPP) and ER $\alpha$ antagonists (MPP dihydrochloride). This finding is in accordance with Jiang et al. (2013) who investigated the interaction of several flavonoid-type phytoestrogens in soybean that contained genistein, daidzein, racemic equol, R-equol, S-equol, liquiritigenin, biochanin-A (monomethyl ether from genistein), and formononetin (monomethyl ether from daidzein) and explained that flavonoids have a lower affinity to bind with $E R \alpha$ that ER $\beta$. Compared to the affinity of $17 \beta$-estradiol with both estrogen receptors, these substances had also lower affinity, i.e., $10 \%$ on $E R \beta$ and $2 \%$ on ER $\alpha$. In this study, the effect of fenugreek 
as a ligand of both estrogen receptors (ER $\alpha$ and $E R \beta)$, similar to the results with flavonoid contained in soybean as the role of ER $\beta$, was stronger than ER $\alpha$.

Chang et al. (2010) pointed out that the management using selective agonist on ER $\beta$ significantly reduced the expression of pro-inflammatory markers, e.g., MMP-1 and interleukin (IL-6) on keratinocytes and fibroblasts, while agonist selective on ER $\alpha$ did not show any contributory effect. In postmenopausal women, estrogen will give the signal to both receptors, especially $\operatorname{ER} \beta$ to delay the skin-aging process.

\section{Speculation on fenugreek's mechanism of action on COL1A1 and COL3A1 secretion}

The administration of $2 \mu \mathrm{g} / \mathrm{ml}$ fenugreek extract increased the secretion of COL1A1 and COL3A1 in HDF. This result was in accordance with previous experimental study (Yusharyahya et al., 2019). Fenugreek extract demonstrated a similar mechanism of action to another phytoestrogen such as soybeans in inhibiting skin-aging process (Jiang et al., 2013; Pilsakova et al., 2010). Although various substances in fenugreek extract can act either as estrogenic or antiestrogenic agents, it is speculated that fenugreek extract had estrogenic effect on the HDF of postmenopausal women. Decreased levels of circulating estrogen in postmenopausal women have an undesirable impact on skin health, thus the administration of estrogen-function phytoestrogens, i.e., fenugreek extract, can trigger the secretion of COL1A1 and COL3A1 from the fibroblast cells.

In this study, the addition of either ER $\alpha$ / ER $\beta$ antagonist or ER $\beta$ antagonist did not successfully suppress the secretion of COL1A1 and COL3A1 fibroblasts until they were exhausted. The role of other estrogen receptor variants or the presence of polymorphisms or epigenetic factors in estrogen receptors, still need to be considered for further research.

\section{CONCLUSION}

We have conducted a research to determine the effect of fenugreek extract as an estrogen agonist on the production of COL1A1 and COL3A1 from HDF, as well as to elaborate which ER subtypes act as mediators for collagen secretion.

This study has successfully opened up an alternative treatment opportunities for aging skin, concluded that the increase in secretion of COL1A1 and COL3A1 on HDF following administration of fenugreek $2 \mu \mathrm{g} / \mathrm{ml}$ extract was mediated mainly through ER $\beta$.

The safety, efficacy, and side effects of long-term exposure of fenugreek extract to improve the production of COL1A1 and COL3A1 from postmenopausal women's skin need a further investigation.

\section{ACKNOWLEDGMENTS}

The authors would like to thank:

Dr. Kurnia Agustini, M.Si, Apt and Agency For The Assessment an Application of Technology (BPPT) in Serpong, Indonesia for supplying fenugreek seeds and throughout the extraction process.

Directorate of Research and Community Engagements Universitas Indonesia for a research grant (Hibah Tugas Akhir Dosen TADOK 2019) for financial support.

\section{REFERENCES}

Aasen T, Raya A, Barrero MJ, Garreta E, Consiglio A, Gonzalez F, Vassena R, Bilić J, Pekarik V, Tiscornia G, Edel M, Boué S, Izpisúa Belmonte JC. Efficient and rapid generation of induced pluripotent stem cells from human keratinocytes. Nat Biotechnol, 2008; 26(11):1276-84; doi: $10.1038 /$ nbt. 1503

Agustini K, Sriningsih S, Effe J. Acute toxicity study of ethanolic extract of fenugreek seeds (Trigonella foenum-graecum L.) on white rats. J Indones Med Plant, 2015; 8(1):9-13.

Borg M, Brincat S, Camilleri G, Schembri-Wismayer P, Brincat M, Calleja-Agius J. The role of cytokines in skin aging. Climacteric, 2013; 16(5):514-21; doi:10.3109/13697137.2013.802303

Calleja-Agius J, Brincat M, Borg M. Skin connective tissue and ageing. Best Pract Res Clin Obstet Gynaecol, 2013; 27(5):727-40; doi:10.1016/j.bpobgyn.2013.06.004

Chang KC, Wang Y, Oh IG, Jenkins S, Freedman LP, Thompson CC, Chung JH, Nagpal S. Estrogen receptor beta is a novel therapeutic target for photoaging. Mol Pharmacol, 2010; 77(5):744-50; doi:10.1124/ mol.109.062877

Chen MN, Lin CC, Liu CF. Efficacy of phytoestrogens for menopausal symptoms: a meta-analysis and systematic review. Climacteric, 2015; 18(2):260-9; doi:10.3109/13697137.2014.966241

Hadi R, Kusuma I, Sandra Y. Allogeneic human dermal fibroblasts are viable in peripheral blood mononuclear co-culture. Univ Med, 2014; 33:91-9; doi:10.1805/UnivMed.2014.v33.91-99

Jia M, Dahlman-Wright K, Gustafsson JA. Estrogen receptor alpha and beta in health and disease. Best Pract Res Clin Endocrinol Metab, 2015; 29(4):557-68; doi:10.1016/j.beem.2015.04.008

Jiang Y, Gong P, Madak-Erdogan Z, Martin T, Jeyakumar M, Carlson K, Khan I, Smillie TJ, Chittiboyina AG, Rotte SC, Helferich WG, Katzenellenbogen JA, Katzenellenbogen BS. Mechanisms enforcing the estrogen receptor beta selectivity of botanical estrogens. FASEB J, 2013; 27(11):4406-4418. doi:10.1096/fj.13-234617

Kammeyer A, Luiten RM. Oxidation events and skin aging. Ageing Res Rev, 2015; 21:16-29; doi:10.1016/j.arr.2015.01.001

Kapuscinska A, Nowak I. The use of phytoestrogens in antiageing cosmetics. Chemik, 2015; 69:154-9.

Kusuma I, Hadi R. Geraniin supplementation increases human keratinocyte proliferation in serum-free culture. Univ Med, 2013; 32:3-10.

Lephart ED. A review of the role of estrogen in dermal aging and facial attractiveness in women. J Cosmet Dermatol, 2018; 17(3):282-8; doi:10.1111/jocd.12508

Nikolić I, Savic-Gajic I, Tačić A, Savic I. Classification and biological activity of phytoestrogens: a review. Adv Technol, 2017; 6:96106; doi:10.5937/savteh1702096N

Panche AN, Diwan AD, Chandra SR. Flavonoids: an overview. J Nutr Sci, 2016; 5:e47; doi:10.1017/jns.2016.41

Parrado C, Mercado-Saenz S, Perez-Davo A, Gilaberte Y, Gonzalez S, Juarranz A. Environmental stressors on skin aging. Mechanistic insights. Front Pharmacol, 2019; 10:759; doi:10.3389/fphar.2019.00759

Pilsakova L, Riecansky I, Jagla F. The physiological actions of isoflavone phytoestrogens. Physiol Res, 2010; 59(5):651-64.

Santoro N, Johnson J. Diagnosing the onset of menopause. JAMA, 2019; 322(8):775-6; doi:10.1001/jama.2019.6250

Strnadova K, Sandera V, Dvorankova B, Kodet O, Duskova M, Smetana K, Lacina L. Skin aging: the dermal perspective. Clin Dermatol, 2019; 37(4):326-35; doi:10.1016/j.clindermatol.2019.04.005

Thornton MJ. Estrogens and aging skin. Dermato-endocrinology, 2013; 5(2):264-70; doi:10.4161/derm.23872

Wani SA, Kumar P. Fenugreek: a review on its nutraceutical properties and utilization in various food products. J Saudi Soc Agric Sci, 2018; 17(2):97-106; doi:10.1016/j.jssas.2016.01.007

Wilkinson HN, Hardman MJ. The role of estrogen in cutaneous ageing and repair. Maturitas, 2017; 103:60-4; doi:10.1016/j. maturitas.2017.06.026 
Yusharyahya SN, Bramono K, Sutanto NR, Kusuma I. The effect of Trigonella foenum-graceum L. (Fenugreek) towards collagen type I alpha 1 (COL1A1) and collagen type III alpha 1 (COL3A1) on postmenopausal woman's fibroblast. Nat Prod Sci, 2019; 25(3):208-14.

\section{How to cite this article:}

Yusharyahya SN, Bramono K, Hestiantoro A, Edwar SQ, Kusuma I. Fenugreek (Trigonella foenum-graceum) increases postmenopausal fibroblast-associated COL1A1 and COL3A1 production dominantly through its binding to estrogen receptor beta. J Appl Pharm Sci, 2020; 10(04):022-027. 